\title{
Prevalence of obesity in a rural Asian Indian (Bangladeshi) population and its determinants
}

Tasnima Siddiquee ${ }^{1}$, Bishwajit Bhowmik ${ }^{1 *}$, Nayla Cristina Da Vale Moreira ${ }^{1}$, Anindita Mujumder ${ }^{3}$, Hajera Mahtab², A. K. Azad Khan ${ }^{2}$ and Akhtar Hussain ${ }^{1}$

\begin{abstract}
Background: Obesity has reached epidemic proportions worldwide including Bangladesh. To assess the prevalence and associated factors of general and central obesity in a rural Bangladeshi population based on newly proposed cut off level for Asian population.

Methods: 2293 subjects aged $\geq 20$ years from rural Bangladesh were randomly recruited to participate in a population-based, cross sectional survey, conducted in 2009. Both socio-demographic and anthropometric measurements were recorded. Age adjusted data for anthropometric indices were examined.
\end{abstract}

Results: The age standardized prevalence of overweight (BMl $23-24.9 \mathrm{~kg} / \mathrm{m}^{2}$ ) and obesity $\left(\mathrm{BMl} \geq 25 \mathrm{~kg} / \mathrm{m}^{2}\right.$ ) were 17.7 (95\% confidence interval (Cl): 16.1, $19.2 \%$ ) and $26.2 \%$ (95\% Cl: 24.4, $27.9 \%$ ), respectively. The age standardized prevalence of central obesity based on WC $(M \geq 90 \& F \geq 80 \mathrm{~cm})$ and WHR $(M \geq 0.90 \& F \geq 0.80)$ were $39.8 \%$ (95 \% Cl: 37.9, $41.7 \%$ ) and $71.6 \%$ (95\% Cl: 69.8, $73.4 \%$ ) respectively. The result shows that prevalence of central obesity was more in female than male. Study shows middle age, medium and high socioeconomic status (SES), low education levels, physical inactivity, high consumption of carbohydrate, protein and fat, were significant risk indicators for general and central obesity. Smoking was shown as protective factor for both general and central obesity.

Conclusions: In rural Bangladeshi population, the prevalence of both general and central obesity was high among both sexes with the use of newly proposed cut off points for Asian population. Gender, diet, physical activity, education levels and SES were associated with the increase prevalence of obesity.

\section{Background}

Obesity in a major public health concern of the twenty first century because of its alarming upward trend in both developed and developing countries $[1,2]$. Obesity is already among the top 10 risks to human health worldwide [3]. According to the WHO report, one in three of the world's adult population is overweight and almost one in 10 is obese. Additionally there are over 20 million children under age five who are overweight [4]. Epidemiological survey used body mass index (BMI) as a measure of general obesity, and waist circumference (WC) and waist hip ratio (WHR) as measures of central/abdominal obesity. Both general and central obesity have been associated with a number of cardiometabolic abnormalities including

\footnotetext{
* Correspondence: doctorbiplob@gmail.com

${ }^{1}$ Department of International Health, Institute of Health and Society, Faculty of Medicine, University of Oslo, P.O. Box 1130, Blindern N-0317 Oslo, Norway Full list of author information is available at the end of the article
}

prediabetes, type 2 diabetes (T2DM), hypertension (HTN), metabolic syndrome (MS) and cardiovascular diseases (CVDs) [5, 6]. Studies in Bangladeshi population have also found similar association at lower BMI, WC and WHR levels [7-9]. The consequence of obesity is not only limited to health consequences but also has an immense effect on individual and national healthcare budget.

Population-based data on the prevalence of obesity and associated factors in Bangladeshi adults have been limited until recently. In 2010, WHO estimated the prevalence of over-weight/obesity (BMI $\geq 25 \mathrm{~kg} / \mathrm{m}^{2}$ ) aged over 15 was $8.4 \%$ in Bangladesh [10]. In another study assessed the prevalence of overweight and obesity among women of reproductive age in South Asia between 1996-2006 also reported increase trends of
() Biomed Central
C 2015 Siddiquee et al. Open Access This article is distributed under the terms of the Creative Commons Attribution 4.0 International License (http://creativecommons.org/licenses/by/4.0/), which permits unrestricted use, distribution, and reproduction in any medium, provided you give appropriate credit to the original author(s) and the source, provide a link to the Creative Commons license, and indicate if changes were made. The Creative Commons Public Domain Dedication waiver (http://creativecommons.org/publicdomain/zero/1.0/) applies to the data made available in this article, unless otherwise stated. 
prevalence. Overweight/obesity prevalence increased from $2.7 \%$ to $8.9 \%$ among Bangladeshi women in 10 years [11]. A recent urban study in Bangladesh has also found increased prevalence of overweight and obesity and it was much higher among those with higher socioeconomic status [12].

Bangladesh is an agro-based rural country where a vast majority (72\%) of the national population lives in rural areas [13], it is important to collect data on the prevalence of obesity and its associated factors. The purposes of the present study are to assess the prevalence of both general and central obesity and their associated factors in a rural Bangladeshi population.

We used the Asian-specific definition to define the prevalence of general and central obesity as it recently suggested by the International Association for the Study of Obesity and the International Obesity Task Force and International Diabetes Federation because of the observed differences in South Asian population [14-16].

\section{Methods}

\section{Study design and participant selection}

This study was part of a large longitudinal epidemiological study on diabetes and related cardiometabolic diseases in rural Bangladesh which has been described previously [17]. This population-based cross-sectional study was conducted in a rural community called Chandra, $40 \mathrm{~km}$. north of Bangladesh's capital, Dhaka during March to December 2009. A total of 10 villages were randomly selected from 25 villages with a population of approximately 20,000 aged $\geq 20$ years. In order to determine the required sample size, the formula: $n=$ $\mathrm{Z}^{2} \mathrm{PQ} / \mathrm{d}^{2}$ was used, where, $\mathrm{Z}=1.96$, $\mathrm{P}$ for prevalence (DM \& impaired glucose regulation) rural area from the previous study [18] i.e. $0.15 ; \mathrm{Q}=1-\mathrm{P}$ i.e. 0.85 and $\mathrm{d}=\mathrm{al}$ lowable error of known prevalence i.e. $0.09 \times 0.15$. Ideally, it should be $0.05 \times 0.15$; but, to be on safe estimation with minimum sample size we allowed only $9 \%$ (or .09) error of prevalence. Thus the calculated sample size was, $n=2687$. Around 3000 individuals (both male and female) aged $\geq 20$ years of those 10 villages were invited to participate in this study by following simple random procedure from the record of the voters lists number; among them 2376 (79.2 \%) agreed individuals were investigated. Regarding non-response, survey timetable in early morning with 2-3 h study time and secondly, the improvement of healthcare facilities in Government Community Clinics may reduce the interest in obtaining a health assessment through the survey. This epidemiological survey was conducted in 20 selected spots of 10 villages. The inclusion criteria's were: both gender, aged $\geq 20$ years and willing to participate. Exclusion criteria included pregnant women, and subjects with self-reported or medical history of myocardial infarction, renal disease, liver disease, tuberculosis, malignant disease and any severe infection at the time of screening.

\section{Data collection and measurements}

Once the selection procedure was completed, participants were requested to visit a nearby field center. The socio-demographic data was collected by interviewing the participants using a predesigned pretested questionnaire. Survey procedures included completing a questionnaire on socio-demographic, physical activity, dietary and smoking information, anthropometric measurements, blood pressure measurement and laboratory investigations. Anthropometric measurements, such as height, weight and waist and hip circumferences, were taken with the participants wearing light clothes and without shoes. The weight was taken to the nearest $0.1 \mathrm{~kg}$ by modern electronic digital LCD weighing machines (Best Deluxe Model; Bathroom, Dhaka, Bangladesh) placed on a flat surface. The scales were calibrated everyday against a standard $(20 \mathrm{~kg})$. Height was taken while the participants stood in erect posture, touching the occiput, back, hip and heels on a straight measuring wall, while the participants looked straight ahead. BMI was calculated as the weight $(\mathrm{kg})$ divided by square of the height $\left(\mathrm{m}^{2}\right)$. Waist circumference was measured by placing a tape horizontally midway between the lower margin of the last palpable rib and iliac crest on the mid-axillary line. Hip circumference was measured at a level parallel to the floor, at the largest circumference of the buttocks. WHR was then calculated from waist and hip circumference $(\mathrm{cm})$. Food consumption and portion sizes were calculated with the 24-h recall method. Participants were asked to report on all foods and drinks consumed in the previous $24 \mathrm{~h}$ (the previous day), in direct chronological order from the first foods in the morning to the last foods before going to bed. A range of local household utensils: glasses, spoons, cups and plates were used for estimating the amount of foods and beverages actually consumed by the respondents. The use of these local utensils acted as visual aids to increase the accuracy of portion size estimations. In some instances the respondent was asked to supply her own utensils for the recall. To obtain the weight/g equivalents of foods, the Bangladesh Food Photo Manual was used, which converts food items of different sizes and composition to gram equivalents. In addition, the respondents were asked to provide information on the following: type of fat/oil used for cooking, preferred cooking method, meal consumption patterns, number of family members use the same kitchen. National Cholesterol Education Program guideline was followed for daily intake of carbohydrate (>55\%), protein (15\%) and fat (>30 \%) [19]. 


\section{Definitions}

Cut-off values for overweight and general obesity for both sexes were BMI $23-24.9 \mathrm{~kg} / \mathrm{m}^{2}$ and BMI of $\geq 25 \mathrm{~kg} / \mathrm{m}^{2}$ respectively; cut-off values for central obesity including waist circumference for male and female were $\geq 90$ and $\geq 80 \mathrm{~cm}$, WHR for male and female were $\geq 0.90$ and $\geq 0.80[14,15]$. Based on the monthly expenditure socio-economic condition was classified as low $(<6000$ Bangladeshi Taka [BDT, 1 USD $=84 \mathrm{BDT}]$ ), medium (6000-11000 BDT) and high (>11000 BDT). Education level graded as illiterate: unable to write and read; having primary and secondary education and college and above. Physical activity was graded on the ordinal scale of 1-3, corresponding to light, moderate and heavy, according to the activity level based on their occupation. For the purpose of data analysis, these results were transformed into a binary variable - inactive (grade1) and active (grade 2 and 3). Smoking habit was classified as either current or non/ex-smoker.

\section{Ethics statement}

The study was carried out in accordance with the declaration of Helsinki as revised in 2000 and all procedures involving for this study were approved by Regional Ethics Committee (REK) of Norway and the Ethics Review Committee (ERC) of Diabetic Association of Bangladesh for Medical Research. Since approximately $52.1 \%$ of the adult population is illiterate [13], an informed verbal consent was received from all subjects or guardians of the subjects prior to inclusion in the study to avoid selection bias. The participants were also verbally informed of their right to withdraw from the study at any stage, or to restrict their data from the analysis. After the verbal information, a printed copy of their rights was given. Both the Ethics Review Committees were satisfied with the voluntary participation, maintenance of the rights of the participating subjects and confidential handling of personal information by the study team and has approved the consent procedure.

\section{Statistical analysis}

The present analysis is based on 2,293 participants (842 male and 1,451 female) for whom all the variables were available. Both STATA 11 for Windows (STATA Co., College Station, TX, USA) and PASW statistics version 18 for Windows (SPSS Inc., Chicago, IL, USA) were used as needed. Means and Percentages with $95 \%$ confidence intervals adjusted for age were given for normally distributed continuous variables and categorical variables as needed. Age specific and age standardized prevalence by direct standardization method were estimated on the basis of 2001 census data before performing statistical tests [20]. Differences between the groups of means and proportions adjusted for age were tested by analysis of covariance (ANCOVA) and logistic regression. Chisquared test was used to test the trend. In the analysis, general (defined by BMI) and central obesity (defined by WC) were considered as the dependent variable. Sociodemographic and dietary factors were included in the regression analysis to identify variables independently associated with overweight and obesity. In the analysis, only those variables which were identified to be independently associated in univariate analyses were included in multinomial models. Statistical inference is based on $95 \%$ confidence intervals (CIs) and the significance level was set at 0.05 .

\section{Results}

Demographic and socio-economic characteristics of the study populations was illustrated in Table 1 . Among the total number of participants, $36.7 \%(n=842)$ were male and $63.3 \%(n=1451)$ were female participants. Females were younger as opposed to male subjects. Among the participants, 23.9, 30.6, 24.5 and $21 \%$ were aged between 20 to 30 years, 31 to 40 years, 41 to 50 years and $\geq 51$ years respectively. A major portion of the participants were Illiterate (45.2\%), and housewives (58.7\%), and $42.2 \%$ and $41.6 \%$ were from middle and low income groups respectively. $15.9 \%$ and $15.1 \%$ participants were cigarette smokers and physically inactive respectively. Mean calorie consumption was $1600 \mathrm{Kcal} /$ day. 90.6, 32.9 and $8.5 \%$ participants consumed recommended level of carbohydrate ( $>55 \%)$, protein $(\geq 15 \%)$ and fat $(>30 \%)$ respectively.

Age specific and age standardized prevalence of BMI levels were shown in Table 2. The age standardized prevalence of underweight, normal weight, overweight and obese were $14.3 \%, 41.9 \%, 17.7 \%$, and $26.2 \%$, respectively. No significant sex difference was observed for the prevalence of BMI levels. With increasing age in female, underweight group showed a significant increasing trend of low BMI.

Age specific and age adjusted mean of body mass index (BMI) by different levels were shown in Table 3. The age adjusted mean of underweight, normal weight, overweight, obese and overall were 17.1, 20.8, 23.9, 27.7 and $22.4 \mathrm{~kg} / \mathrm{m}^{2}$ respectively. Significant difference between the two sexes was noticed in the age adjusted mean of obese group $\left(27.3 \mathrm{~kg} / \mathrm{m}^{2}\right.$ in male and $27.9 \mathrm{~kg} / \mathrm{m}^{2}$ in female; $P<0.05)$.

Age specific and age standardized prevalence of central obesity based on Waist circumference (WC) and Waist hip ratio (WHR) were shown in Table 4. The age standardized prevalence of central obesity following WC and WHR were $39.8 \%$ and $71.6 \%$ respectively. Central obesity by WC and WHR were more in female than male. Age specific prevalence of central obesity, for both WC and WHR showed significant sex differences. The prevalence of central obesity by WHR demonstrated that 
Table 1 Demographic and socio-economic characteristics of the study subjects $(n=2293)$

\begin{tabular}{|c|c|c|c|}
\hline \multicolumn{2}{|l|}{ Variables } & \multicolumn{2}{|c|}{ Number } \\
\hline \multirow[t]{3}{*}{ Age } & Total Participants & 2293 & $41.8(41.2,42.4)$ \\
\hline & Male & 842 & $44.3(43.3,45.2)$ \\
\hline & Female & 1451 & $40.4(39.7,41.1)$ \\
\hline \multirow[t]{4}{*}{ Age group (year), \% } & $20-30$ & 548 & 23.9 \\
\hline & $31-40$ & 702 & 30.6 \\
\hline & $41-50$ & 562 & 24.5 \\
\hline & $\geq 51$ & 481 & 21.0 \\
\hline \multirow[t]{4}{*}{ Education, \% } & Illiterate & 1037 & 45.2 \\
\hline & Primary (0-5 class) & 419 & 18.3 \\
\hline & Secondary (6-10 class) & 627 & 27.3 \\
\hline & College (>10 class) \& above & 210 & 9.2 \\
\hline \multirow[t]{5}{*}{ Occupation, \% } & Farmer & 443 & 19.3 \\
\hline & Business & 199 & 8.7 \\
\hline & Skill labour & 112 & 4.8 \\
\hline & Manual labour & 194 & 8.5 \\
\hline & Housewives & 1345 & 58.7 \\
\hline \multirow[t]{3}{*}{ Socioeconomic status, \% } & Low income $(<6000$ BDT) & 953 & 41.6 \\
\hline & Middle income (6000-11000 BDT) & 967 & 42.2 \\
\hline & High income (>11000 BDT) & 373 & 16.3 \\
\hline Smoking habit, \% & Cigarette smoking & 365 & 15.9 \\
\hline \multirow[t]{2}{*}{ Physical activity, \% } & Active & 1946 & 84.9 \\
\hline & Inactive & 347 & 15.1 \\
\hline \multirow[t]{4}{*}{ Calorie consumption } & Total calorie intake (kcal/day) & 2293 & $1600(1587-1613)$ \\
\hline & Carbohydrate (>55 \%) & 2077 & 90.6 \\
\hline & Protein ( $\geq 15 \%)$ & 754 & 32.9 \\
\hline & Fat (>30 \%) & 196 & 8.5 \\
\hline
\end{tabular}

Data expressed as $\%$ or mean $\pm 95 \% \mathrm{Cl}$. Cl, confidence interval

a significant increasing trend of central obesity among female subjects with increasing age.

Age specific and age adjusted mean of waist circumference (WC) and waist hip ratio (WHR), by sex was shown in Table 5. The age adjusted mean of central obesity following WC and WHR were $80.5 \mathrm{~cm}$ and 0.88 respectively. Significant difference by gender was noted in the age adjusted mean of central obesity by WC $(81.8 \mathrm{~cm}$ in male and $79.7 \mathrm{~cm}$ in female; $P<0.05)$ and WHR (0.91 in male and 0.86 in female; $P<0.05)$. This was also observed in age specific mean of central obesity, both WC and WHR groups including the mean of central obesity following WC and WHR among age groups.

Table 6 showed middle age, medium and high SES, irrespective of education levels, physical inactivity, high consumption of carbohydrate, protein and fat, were some significant risk indicator for general and central obesity in both unadjusted and adjusted models. In addition, females had significant higher risk for central obesity. Smoking was found to have a protective effect for both general and central obesity.

\section{Discussion}

This current study was undertaken to explore the prevalence of overweight, obesity and central obesity (abdominal obesity) and their associated socio-demographic and lifestyle determinants in a rural Bangladeshi population aged $\geq 20$ years and older.

For this current study, we have used newly proposed cut-off levels for Asian population for defining general and central obesity. Evidence shows that Asian Indians including Indian [21], Pakistani [22], Sri Lankan [23] and Bangladeshi [7-9] generally have a lower BMI than many other ethnic population, but the association between BMI and cardiometabolic risk factors is as strong as in any other population. The risk of diabetes and other cardiometabolic factors were significant for Bangladeshi populations with a BMI of $>21 \mathrm{~kg} / \mathrm{m}^{2}$ [7-9] and this has been confirmed by studies in other Asian 
Table 2 Age specific and age standardized prevalence of different Body Mass Index (BMI) levels ( $n=2293)$

\begin{tabular}{|c|c|c|c|c|c|}
\hline \multirow[t]{2}{*}{ Variables } & \multicolumn{4}{|c|}{ Age specific (year) prevalence, $\%$} & \multirow{2}{*}{$\begin{array}{l}\text { Age Standardized prevalence, \% (95 \% Cl) } \\
20-80 \text { years }\end{array}$} \\
\hline & $20-30(n=548)$ & $31-40(n=702)$ & $41-50(n=562)$ & $\geq 51(n=481)$ & \\
\hline \multicolumn{6}{|c|}{ Underweight $\left(\mathrm{BMI}<18.5 \mathrm{Kg} / \mathrm{m}^{2}\right)$} \\
\hline Total $(n=328)$ & 11.7 & 10.3 & 16.2 & 21.0 & $14.3(12.9,15.7)$ \\
\hline Male & 14.6 & 9.1 & 14.3 & 18.6 & $13.6(11.3,16.0)$ \\
\hline Female & 10.4 & 10.9 & 17.5 & $23.1^{\mathrm{a}}$ & $14.9(12.1,16.8)$ \\
\hline \multicolumn{6}{|c|}{ Normal weight (BMI 18.5- $<23 \mathrm{Kg} / \mathrm{m}^{2}$ ) } \\
\hline Total $(n=960)$ & 46.2 & 39.2 & 41.1 & 41.8 & $41.9(39.9,43.9)$ \\
\hline Male & 44.2 & 41.4 & 41.1 & 42.9 & $42.3(38.9,45.7)$ \\
\hline Female & 47.0 & 38.9 & 41.1 & 40.8 & $41.5(38.9,44.1)$ \\
\hline \multicolumn{6}{|c|}{ Overweight (BMI 23-<25 Kg/m²) } \\
\hline Total $(n=405)$ & 18.6 & 17.1 & 17.6 & 17.5 & $17.7(16.1,19.2)$ \\
\hline Male & 18.8 & 19.8 & 17.9 & 19.9 & $19.1(16.5,21.8)$ \\
\hline Female & 18.5 & 15.7 & 17.5 & 15.4 & $16.8(14.9,18.7)$ \\
\hline \multicolumn{6}{|c|}{ Obese (BMl $\geq 25 \mathrm{Kg} / \mathrm{m}^{2}$ ) } \\
\hline Total $(n=600)$ & 23.7 & 33.5 & 25.1 & 19.8 & $26.2(24.4,27.9)$ \\
\hline Male & 22.4 & 29.7 & 26.8 & 18.6 & $25.1(22.1,28.0)$ \\
\hline Female & 24.0 & 35.3 & 23.9 & 20.8 & $26.8(24.5,29.0)$ \\
\hline
\end{tabular}

Values are presented as \% (number) or (95\% confidence interval) as indicated. Age adjustment was based on 2001 census of Bangladesh ${ }^{a} X^{2}$ trend $=P<0.05$ for different age group. $\mathrm{Cl}$, confidence interval; $\mathrm{BMI}$, body mass index

Table 3 Age specific and Age adjusted mean of Body Mass Index (BMI) by different levels ( $n=2293$ )

\begin{tabular}{|c|c|c|c|c|c|}
\hline & \multicolumn{4}{|c|}{ Age specific (year) means (95\% Cl) } & \multirow{2}{*}{$\begin{array}{l}\text { Age adjusted } \\
\text { mean }(95 \% \mathrm{Cl})\end{array}$} \\
\hline & $20-30(n=548)$ & $31-40(n=702)$ & $41-50(n=562)$ & $\geq 51(n=481)$ & \\
\hline \multicolumn{6}{|c|}{ Underweight $(N=328)$} \\
\hline Total & $17.1(16.8,17.3)$ & $17.5(17.3,17.7)$ & $17.1(16.9,17.4)$ & $16.7(16.5,16.9)$ & $17.1(16.9,17.2)$ \\
\hline Male & $17.0(16.5,17.5)$ & $17.6(17.2,18.1)$ & $17.2(16.7,17.7)$ & $16.8(16.4,17.2)$ & $17.1(16.9,17.3)$ \\
\hline Female & $17.1(16.8,17.4)$ & $17.5(17.2,17.7)$ & $17.1(16.8,17.4)$ & $16.7(16.4,17.2)$ & $17.1(16.9,17.2)$ \\
\hline \multicolumn{6}{|c|}{ Normal weight $(N=960)$} \\
\hline Total & $20.8(20.6,20.9)$ & $20.8(20.6,20.9)$ & $20.9(20.7,21.0)$ & $20.8(20.6,23.0)$ & $20.8(20.7,20.9)$ \\
\hline Male & $20.7(20.4,21.0)$ & $20.8(20.6,21.1)$ & $20.8(20.5,21.1)$ & $20.8(20.5,21.0)$ & $20.8(20.7,20.9)$ \\
\hline Female & $20.8(20.6,21.0)$ & $20.8(20.6,20.9)$ & $20.9(20.7,21.1)$ & $20.8(20.6,21.1)$ & $20.8(20.7,20.9)$ \\
\hline \multicolumn{6}{|c|}{ Overweight $(N=405)$} \\
\hline Total & $23.9(23.8,24.1)$ & $23.9(23.8,24.1)$ & $23.9(23.8,24.0)$ & $23.9(23.8,24.0)$ & $23.9(23.8,24.0)$ \\
\hline Male & $23.9(23.7,24.1)$ & $23.9(23.8,24.2)$ & $23.9(23.8,24.0)$ & $23.9(23.7,24.0)$ & $23.9(23.8,24.0)$ \\
\hline Female & $24.0(23.8,24.1)$ & $24.0(23.8,24.1)$ & $23.9(23.8,24.1)$ & $23.9(23.8,24.0)$ & $23.9(23.8,24.0)$ \\
\hline \multicolumn{6}{|c|}{ Obese $(N=600)$} \\
\hline Total & $27.6(27.2,28.0)$ & $27.9(27.6,28.2)$ & $27.6(27.2,28.0)$ & $27.3(26.8,27.7)$ & $27.7(27.5,27.9)$ \\
\hline Male & $27.3(26.6,27.9)$ & $27.3(26.9,27.7)$ & $27.4(26.7,28.1)$ & $27.1(26.3,27.8)$ & $27.3(27.0,27.6)$ \\
\hline Female & $27.3(27.0,28.3)$ & $28.2(27.8,28.6)$ & $27.7(27.2,28.2)$ & $27.4(26.9,28.0)$ & $27.9(27.7,28.1)^{b}$ \\
\hline \multicolumn{6}{|c|}{ Overall $(N=2293)$} \\
\hline Total & $22.6(22.2,22.9)$ & $23.4(23.1,23.7)$ & $22.5(22.2,22.8)$ & $21.8(21.4,22.1)$ & $22.4(22.3,22.5)$ \\
\hline Male & $22.3(21.7,22.8)$ & $23.1(22.6,23.5)$ & $22.6(22.1,23.1)$ & $21.8(21.3,22.3)$ & $22.3(22.2,22.4)$ \\
\hline Female & $22.7(22.3,23.1)$ & $23.5(23.2,23.9)$ & $22.4(21.9,22.8)$ & $21.7(21.2,22.2)$ & $22.4(22.3,22.5)$ \\
\hline
\end{tabular}


Table 4 Age specific and age standardized prevalence of central obesity based on Waist circumference (WC) and Waist hip ratio (WHR)

\begin{tabular}{|c|c|c|c|c|c|}
\hline \multirow[t]{2}{*}{ Variables } & \multicolumn{4}{|c|}{ Age specific (year) prevalence, $\%$} & \multirow{2}{*}{$\begin{array}{l}\text { Age Standardized prevalence, } \% \text { (95\% Cl) } \\
20-80 \text { years }\end{array}$} \\
\hline & $20-30(n=548)$ & $31-40(n=702)$ & $41-50(n=562)$ & $\geq 51(n=481)$ & \\
\hline \multicolumn{6}{|l|}{ Central Obesity by WC (cm) } \\
\hline Total $(M \geq 90 \& F \geq 80)$ & 34.9 & 46.3 & 41.6 & 33.9 & $39.8(37.9,41.7)$ \\
\hline Male $(\geq 90 \mathrm{~cm})$ & 16.4 & 28.9 & 29.9 & 19.9 & $24.3(21.4,27.1)$ \\
\hline Female $(\geq 80 \mathrm{~cm})$ & 42.8 & 54.9 & 49.4 & 45.8 & $48.7(46.2,51.3)^{b}$ \\
\hline \multicolumn{6}{|l|}{ Central Obesity by WHR } \\
\hline Total $(M \geq 0.90 \& F \geq 0.80)$ & 66.6 & 73.1 & 73.8 & $72.6^{\mathrm{a}}$ & $71.6(69.8,73.4)$ \\
\hline Male $(\geq 0.90)$ & 43.6 & 64.7 & 63.4 & $60.6^{\mathrm{a}}$ & $58.4(55.2,61.8)$ \\
\hline Female $(\geq 0.80)$ & 76.5 & 77.2 & 80.8 & $82.7^{\mathrm{a}}$ & $79.1(76.9,81.1)^{\mathrm{b}}$ \\
\hline
\end{tabular}

Values are presented as \% (number) or (95\% confidence interval) as indicated. Age adjustment was based on 2001 census of Bangladesh $\mathrm{Cl}$, confidence interval

${ }^{a} X^{2}$ trend $=P<0.05$ Central Obesity based on WC and WHR, ${ }^{b} P<0.05$ between male and female same group

populations [21-23]. WHO also recommend, a BMI of $18.5-22 \mathrm{~kg} / \mathrm{m}^{2}$ is considered healthy for Asian populations [24]. Similarly, lower central obesity cut- off levels have also been recommended for the South Asians [16, 21].

The age standardized prevalence of overweight (BMI $23-24.9 \mathrm{~kg} / \mathrm{m}^{2}$ ) and obesity (BMI $\geq 25 \mathrm{~kg} / \mathrm{m}^{2}$ ) in current study were 17.7 and $26.2 \%$ respectively. The prevalence of obesity documented in this study was comparatively higher than previous studies in Bangladesh conducted in different time points using different anthropometric cutoff levels [11, 25]. The rate was also found higher than rural areas of China, Greece and north India [26-28]; however, they used WHO cut-off levels for western population. In this study, age standardized prevalence of central obesity based on WC $(\mathrm{M} \geq 90 \& \mathrm{~F} \geq 80 \mathrm{~cm})$ and WHR $(M \geq 0.90 \& F \geq 0.80)$ were $39.8 \%$ and $71.6 \%$ respectively. The rate of central obesity was higher than general obesity in our study which indicate a significant portion of the population may not classified as obese on BMI levels. Hence, it has been suggested that a single BMI cut-off level for both male and female might not be adequate to define general obesity. Gender, age and ethnic specific BMI levels for defining general obesity might be preferable.

Study demonstrated that high prevalence of obesity was positively associated with female sex, middle age, higher educational and economic status, physical inactivity and some dietary habits in South Asian region [29]. For instance, similar findings were observe in our study except education level. In our study, the prevalence of obesity is slightly higher in female than male, while overweight is more prevalent in male. Our results are in agreements with the study conducted in Pakistan [30], South India [31] and Ghana [32] where prevalence of obesity was found to be higher among female than male. However, in Japan, male were more obese than female [33]. In the present analysis, rate of central obesity was also higher in female participants which is consistence with the study conducted in south India [31]. Increased parity, menopause, high rate of oral contraceptive pill intake and low level of cigarette smoking could be the possible contributors of high level of central obesity in females. Study findings indicate that our study population are at risk for cardiometabolic diseases. Findings

Table 5 Age specific and age adjusted mean of Waist circumference (WC) and Waist hip ratio (WHR), by sex

\begin{tabular}{|c|c|c|c|c|c|}
\hline \multirow[t]{2}{*}{ Variables } & \multicolumn{4}{|c|}{ Age specific (year) means, $95 \% \mathrm{Cl}$} & \multirow{2}{*}{$\begin{array}{l}\text { Age adjusted } \\
\text { Mean }(95 \% \mathrm{Cl})\end{array}$} \\
\hline & $20-30(n=548)$ & $31-40(n=702)$ & $41-50(n=562)$ & $\geq 51(n=481)$ & \\
\hline \multicolumn{6}{|l|}{ Central Obesity by WC $(\mathrm{cm})$} \\
\hline Total $(M \geq 90 \& F \geq 80)$ & $79.2(78.4,80.1)$ & $81.8(81.6,82.6)$ & $81.0(80.1,81.8)$ & $79.5(78.4,80.4)^{\mathrm{a}}$ & $80.5(80.1,80.9)$ \\
\hline Male $(\geq 90 \mathrm{~cm})$ & $80.0(78.4,81.5)$ & $83.1(81.9,84.3)$ & $82.8(81.4,84.1)$ & $80.8(79.4,82.2)$ & $81.8(81.1,82.5)$ \\
\hline Female $(\geq 80 \mathrm{~cm})$ & $78.9(77.9,79.9)$ & $81.2(80.2,82.2)$ & $79.8(78.7,80.9)$ & $78.2(76.8,79.7)^{a}$ & $79.7(79.2,80.3)^{b}$ \\
\hline \multicolumn{6}{|l|}{ Central Obesity by WHR } \\
\hline Total $(M \geq 0.90 \& F \geq 0.80)$ & $0.86(0.85,0.87)$ & $0.88(0.86,0.89)$ & $0.89(0.88,0.90)$ & $0.89(0.88,0.90)^{\mathrm{a}}$ & $0.88(0.87,0.89)$ \\
\hline Male $(\geq 0.90)$ & $0.89(0.87,0.90)$ & $0.91(0.90,0.92)$ & $0.92(0.91,0.93)$ & $0.91(0.90,0.92)$ & $0.91(0.90,0.93)$ \\
\hline Female $(\geq 0.80)$ & $0.85(0.84,0.86)$ & $0.86(0.85,0.87)$ & $0.87(0.86,0.88)$ & $0.87(0.86,0.88)^{a}$ & $0.86(0.85,0.87)^{\mathrm{b}}$ \\
\hline
\end{tabular}

Values are presented as mean (95\% confidence interval). Age adjustment was based on 2001 census of Bangladesh

$\mathrm{Cl}$, confidence interval. ${ }^{\mathrm{a}} P<0.05$ between age group: ${ }^{\mathrm{b}} \mathrm{P}<0.05$ between male and female in same group 
Table 6 Association between general (BMI $\geq 25 \mathrm{Kg} / \mathrm{m} 2)$ and central obesity (WC: $M \geq 90$ \& F $\geq 80$ ) and socio-demographic and dietary factors in the surveyed population aged $\geq 20$ years

\begin{tabular}{|c|c|c|c|c|c|c|}
\hline \multirow[b]{2}{*}{ Variables } & \multicolumn{3}{|l|}{ General obesity } & \multicolumn{3}{|l|}{ Central obesity } \\
\hline & Unadjusted OR (95 \% Cl) & Adjusted OR (95 \% Cl) & $P$ value & Unadjusted OR (95 \% Cl) & Adjusted OR (95 \% Cl) & $P$ value \\
\hline \multicolumn{7}{|l|}{ Age (years) } \\
\hline $20-30$ & Ref & Ref & & Ref & Ref & \\
\hline $31-40$ & $1.62(1.26,2.08)$ & $1.63(1.25,2.13)$ & $<0.001$ & $1.61(1.28,2.02)$ & $1.69(1.32,2.16)$ & $<0.001$ \\
\hline $41-50$ & $1.08(0.82,1.42)$ & $1.22(0.84,1.49)$ & 0.431 & $1.33(1.05,1.70)$ & $1.56(1.20,2.03)$ & 0.001 \\
\hline$\geq 51$ & $0.79(0.59,1.07)$ & $0.75(0.54,1.03)$ & 0.075 & $0.96,(0.74,1.24)$ & $1.05(0.79,1.38)$ & 0.741 \\
\hline \multicolumn{7}{|l|}{ Sex } \\
\hline Male & Ref & Ref & & Ref & Ref & \\
\hline Female & $1.13(0.93,1.38)$ & $1.05(0.81,1.35)$ & 0.739 & $2.96(2.45,3.57)$ & $3.70(2.86,4.79)$ & $<0.001$ \\
\hline \multicolumn{7}{|l|}{ Education } \\
\hline Higher & Ref & Ref & & Ref & Ref & \\
\hline Secondary & $2.85(1.85,4.39)$ & $2.34(1.49,3.67)$ & $<0.001$ & $3.32(2.32,4.74)$ & $2.13(1.47,3.91)$ & $<0.001$ \\
\hline Primary & $2.81(1.78,4.47)$ & $2.84(1.79,4.51)$ & $<0.001$ & $2.65(1.79,3.90)$ & $2.65(1.79,3.91)$ & $<0.001$ \\
\hline Illiterate & $2.33(1.49,3.65)$ & $2.87(1.86,4.42)$ & $<0.001$ & $2.12(1.47,3.09)$ & $3.32(2.33,4.74)$ & $<0.001$ \\
\hline \multicolumn{7}{|l|}{ SES } \\
\hline Low & Ref & Ref & & Ref & Ref & \\
\hline Medium & $1.68(1.35,2.08)$ & $1.69(1.35,2.12)$ & $<0.001$ & $1.41(1.17,169)$ & $1.59(1.30,1.94)$ & $<0.001$ \\
\hline High & $3.62(2.78,4.70)$ & $3.42(2.60,4.50)$ & $<0.001$ & $2.52(1.98,3.22)$ & $2.91(2.24,3.81)$ & $<0.001$ \\
\hline \multicolumn{7}{|l|}{ Smoking } \\
\hline No & Ref & Ref & & Ref & Ref & \\
\hline Yes & $0.51(0.38,0.68)$ & $0.48(0.34,0.68)$ & $<0.001$ & $0.75(0.57,0.96)$ & $0.70(0.51,0.97)$ & 0.031 \\
\hline \multicolumn{7}{|c|}{ Physical activity } \\
\hline active & Ref & Ref & & Ref & Ref & \\
\hline inactive & $1.42(1.10,1.82)$ & $1.58(1.17,2.14)$ & 0.003 & $1.80(1.42,2.48)$ & $1.78(1.32,2.39)$ & $<0.001$ \\
\hline \multicolumn{7}{|c|}{ CHO intake (\%) } \\
\hline$\leq 55 \%$ & Ref & Ref & & Ref & Ref & \\
\hline$>55 \%$ & $2.72(1.99,3.93)$ & $2.78(2.00,4.00)$ & $<0.001$ & $2.97(2.76,3.72)$ & $2.87(2.04,4.05)$ & $<0.001$ \\
\hline \multicolumn{7}{|c|}{ Protein intake (\%) } \\
\hline$<15 \%$ & Ref & Ref & & Ref & Ref & \\
\hline$\geq 15 \%$ & $1.45(1.11,1.76)$ & $1.25(1.01,1.55)$ & 0.039 & $1.52(1.25,1.63)$ & $1.26(1.02,1.56)$ & 0.036 \\
\hline \multicolumn{7}{|c|}{ Fat intake (\%) } \\
\hline$<30 \%$ & Ref & Ref & & Ref & Ref & \\
\hline$\geq 30 \%$ & $2.20(1.35,2.79)$ & $1.78(1.19,2.65)$ & 0.005 & $2.18(1.85,2.67)$ & $1.78(1.19,2.67)$ & 0.005 \\
\hline
\end{tabular}

Adjusted by age, sec, educational status, socioeconomic status (SES), smoking, physical activity, depression, carbohydrate, protein and fat intake. BMI, body mass index; WC, waist circumference, SES, socio-economic status, $\mathrm{CHO}$, carbohydrate

emphasis the need for effective intervention with community based approaches to prevent and treat obesity.

We have observed that the highest prevalence of obesity in South Asians is observed in the middle aged (3050 years) group, whereas in the western countries prevalence tends to increase progressively with age [34]. The highest prevalence was reached in the middle-aged (30-40 years) group in our study. In this study, we have found that people with lower levels of education and higher socioeconomic status had the higher rate of obesity. Similar finding was supported by other studies conducted in Australia, Greece, and Canada [35, 36, 28], although the cause in our study is not clear. Further long term well design study are needed to know the exact cause of this contrasting finding between education and SES. Possible hypothesis could be, majority of participants are farmers, businessmen, manual labors and housewives, and for these formal education are not mandatory. Due to continued economic growth and huge development in agricultural sectors in last few 
years now they have a good income. They can afford foods but due to lack of proper education they are not aware of healthy diet. They mainly eat rice, hydrogenated oil and sugar. All of these are known to increase the risk of weight gain. Evidence shows the global epidemic of obesity has resulted mainly from societal factors that promote increased availability of high-fat energy-dense foods, excess carbohydrate based diet, and physical inactivity. Physical inactivity, high intake of carbohydrate, protein and fat, were significant risk indicators for general and central obesity in our study.

Smoking was protective factor for general and central obesity in our study which is consistence with the studies were conducted in Australia, Portugal, Spain and Switzerland [35, 37-39]. Possible biological mechanism may explain the inverse association between smoking and obesity. Study has shown that smoking increase resting metabolic rate and thermogenesis, but also reduce energy intake and since it provides the smoker with a diminished sense of taste and smell, which makes food less attractive and therefore less is consumed which ultimately cause less weight gain [29].

The strength of the study that it was a large scale population based study where response rate was $79.0 \%$. Bias was taken care of by random sampling. Anthropometric measurements were done by the highly trained interviewers. The present study had several limitations. The major limitation was the cross-sectional design, which cannot establish causal relations. Therefore, we cannot say the identified risk factors are causally associated with both general and central obesity. Subject exclusion based on self-reported personal medical history was another limitation of the present study. The study was conducted in a rural area of Bangladesh adjacent to capital Dhaka city. Hence, the result may be interpreted with caution.

\section{Conclusion}

It is apparent that obesity is increasing even in rural adult population. In rural Bangladeshi population, the rate of general and central obesity was high among both sexes with the use of newly proposed cut off points for Asian population. Central obesity was more in females than males. Gender, diet, physical activity, education level, SES, and smoking were associated with the prevalence of obesity. Along with socio-economic determinants, our rural population are less likely to receive counseling regarding healthy diet and exercise habits may place them in a more vulnerable position with respect to developing obesity over time. Nationally representative and longitudinal follow-up studies including all the possible influences are needed to confirm the risk indicators for obesity found in this study. The study indicates that intervention program is needed to identify practical, effective and acceptable methods for prevention of obesity. Finally, Government policy makers and other health related stakeholders should consider obesity as a growing public issue and therefore, an urgent need for national program to reduce obesity and associated comorbidity and mortality.

\section{Competing interests}

The authors declare that they have no competing interests.

\section{Authors' contributions}

TS, BB were involved in designed the protocol, carried out the field work, performed the data analysis, and drafted the manuscript. NCD participated in drafting the manuscript. $\mathrm{HM}, \mathrm{AK}$ and $\mathrm{AH}$ participated in the design of the study and edited the manuscript. All authors read and approved the final manuscript.

\section{Acknowledgments}

We acknowledge the contribution of our survey team members, the village leaders and volunteers for their continuous effort in the collection of data. We are grateful to all participants in the study for their active co-operation. We also express our admiration to the authority of the Diabetic Association of Bangladesh for providing us with local logistic support, and the University of Oslo for their financial support.

\section{Author details}

${ }^{1}$ Department of International Health, Institute of Health and Society, Faculty of Medicine, University of Oslo, P.O. Box 1130, Blindern N-0317 Oslo, Norway. ${ }^{2}$ Department of Endocrinology, Bangladesh Institute of Research and Rehabilitation in Diabetes, Endocrine and Metabolic Disorders (BIRDEM), Dhaka 1200, Bangladesh. ${ }^{3}$ Department of Pathology, Ibrahim Medical College, Diabetic Association of Bangladesh, Dhaka 1200, Bangladesh.

Received: 1 August 2014 Accepted: 27 August 2015

Published online: 04 September 2015

\section{References}

1. Popkin BM. The nutrition transition and obesity in the developing world. J Nutr. 2001;131:871S-73S.

2. York DA, Rössner S, Caterson I, Chen CM, James WP, Kumanyika S, et al. Obesity, a worldwide epidemic related to heart disease and stroke: worldwide demographics of obesity. Circulation. 2004;110:463-70.

3. World Health Organization. World Health Report 2002 - Reducing risks, promoting healthy life. Geneva: WHO; 2002.

4. WHO I Obesity and overweight. http://www.who.int/mediacentre/ factsheets/fs311/en/index.html

5. Balkau B, Deanfield JE, Després JP, Bassand JP, Fox KA, Smith Jr SC, et al. International Day for the Evaluation of Abdominal Obesity (IDEA): a study of waist circumference, cardiovascular disease, and diabetes mellitus in 168,000 primary care patients in 63 countries. Circulation. 2007;116:1942-51.

6. Casanueva FF, Moreno B, Rodríguez-Azeredo R, Massien C, Conthe P, Formiguera $X$, et al. Relationship of abdominal obesity with cardiovascular disease, diabetes and hyperlipidaemia in Spain. Clin Endocrinol (Oxf). 2010;73:35-40.

7. Bhowmik B, Munir SB, Ahmed KR, Siddiquee T, Diep LM, Wright E, et al. Anthropometric indices of obesity and type 2 diabetes in Bangladeshi population: Chandra Rural Diabetes Study (CRDS). J Orcp. 2014;8:e220-9.

8. Bhowmik B, Munir SB, Diep LM, Siddiquee T, Habib SH, Samad MA, et al. Anthropometric indicators of obesity for identifying cardiometabolic risk factors in a rural Bangladeshi population. J Diabetes Invest. 2013;4:361-8.

9. Siddiquee T, Bhowmik B, Karmaker RK, Chowdhury A, Mahtab H, Azad Khan AK, Hussain A: Association of general and central obesity with diabetes and prediabetes in rural Bangladeshi population. Diabetes Metab Syndr. 2015 Mar 5. doi:10.1016/j.dsx.2015.02.002.

10. The SuRF Report 2 - World Health Organization. https://apps.who.int/ infobase/Publicfiles/SuRF2.pdf

11. Balarajan Y, Villamor. Trends in overweight in South Asian women. J Nutr. 2009;139:2139-44. 
12. Das SK, Chisti MJ, Huq S, Malek MA, Vanderlec L, Salam MA, et al. Changing Trend of Overweight and Obesity and Their Associated Factors in an Urban Population of Bangladesh. Food Nutr Sci. 2013;4:678-89.

13. CIA-The World Fact book. https://www.cia.gov/library/publications/theworldfact book/geos/bg.html.(accessed October 4 2012).

14. Choo V. WHO reassesses appropriate body-mass index for Asian populations. Lancet. 2002;360:235.

15. World Health Organization, Western Pacific Region. The International Association for the Study of Obesity and the International Obesity Task Force. The Asia-Pacific Perspective: Redefining Obesity and its Treatment. Health Communications Australia Pty Limited, Sydney, Australia, 2000. Available at: www.wpro.who.int/nutrition/documents/docs/ Redefiningobesity.pdf (Last accessed August 23 2006).

16. Alberti KG, Zimmet P, Shaw J. IDF Epidemiology Task Force Consensus Group. The metabolic syndrome: a new worldwide definition. Lancet. 2005;366:1059-62.

17. Hussain A, Rahim MA, Azad Khan AK, Ali SM, Vaaler S. Type 2 diabetes in rural and urban population: diverse prevalence and associated risk factors in Bangladesh. Diabet Med. 2005;22:931-6.

18. Rahim MA, Khan AK, Ali SM, Nahar Q, Shaheen A, Hussain A. Glucose tolerance in a rural population of Bangladesh. Int J Diabetes Dev Ctries. 2008;28:45-50.

19. Expert panel on Detection, Evaluation, and Treatment of High Blood Cholesterol in Adults Executive Summary of the Third Report of the National Cholesterol Education Program (NCEP) Expert Panel on Detection, Evaluation, and Treatment of High Blood Cholesterol in Adults (Adult Treatment Panel III). JAMA 2001, 285: 2486-2497. www.nhlbi.nih.gov/files/ docs/guidelines/atp3xsum.pdf

20. Bangladesh Bureau of Statistics. Statistical pocket book of Bangladesh. Dacca: Statistical Division, Ministry of Planning; 2001.

21. Misra A, Vikram N, Gupta R, Pandey R, Wasir J, Gupta V. Waist circumference cutoff points and action levels for Asian Indians for identification of abdominal obesity. Int J Obes (Lond). 2005;30:106-11.

22. Jafar TH, Chaturvedi N, Pappas G. Prevalence of overweight and obesity and their association with hypertension and diabetes mellitus in an Indo-Asian population. CMAJ. 2006;175:1071-7.

23. Katulanda $P$, Jayawardena MA, Sheriff MH, Matthews DR. Derivation of anthropometric cut-off levels to define CVD risk in Sri Lankan adults. Br J Nutr. 2011;105:1084-90.

24. Report of WHO Consultation, "Obesity: preventing and managing the global epidemic", World Health Organization - Technical Report Series. 20 Avenue Appia, 1211 Geneva 27, Switzerland; 2000. no. 894, pp. 1-253.

25. Talukder K, Talukder M, Bhadra S, Talukder M Increasing trend of BMI 23 in Bangladeshi mothers of children aged less than five years. Dhaka: 8th Commonwealth Congress on Diarrhoea and Malnutrition (CAPGAN), 2006.

26. Zhang X, Sun Z, Zhang X, Zheng L, Liu S, Xu C, et al. Prevalence and Associated Factors of Overweight and Obesity in a Chinese Rural Population. Obesity. 2008;16:168-71.

27. Panagiotakos DB, Pitsavos C, Chrysohoou C, Risvas G, Kontogianni MD, Zampelas A, et al. Epidemiology of overweight and obesity in a Greek adult population: the ATTICA study. Obes Res. 2004;12:1914-20.

28. Chadha SL, Gopinath N, Shekhawat S. Urban-rural differences in the prevalence of coronary heart disease and its risk factors in Delhi. Bull World Health Organ. 1997;75:31-8.

29. Jayawardena R, Byrne NM, Soares MJ, Katulanda P, Hills AP. Prevalence, Trends and Associated Socio-Economic Factors of Obesity in South Asia. Obes Facts. 2013;6:405-14.

30. Shah S, Hussain A, Jafar T, Reeder B. Obesity in a South Asian population: trends between 1995 and 2007. Obes Rev. 2010;11:59.

31. Kaur P, Rao SR, Radha Krishnan E, Rajasekar D, Gupte MD. Prevalence, awareness, treatment, control and risk factors for hypertension in a rural population in South India. Int J Public Health. 2012;57:87-94.

32. Biritwum R, Gyapong J, Mensah G. The epidemiology of obesity in Ghana. Ghana Med J. 2005:39:82-5.

33. Aoyagi K, Kusano Y, Takamura N, Abe Y, Osaki M, Une H. Obesity and cardiovascular risk factors among men and women aged 40 years and older in a rural area of Japan. J Physiol Anthropol. 2006;25:371-5.

34. Rennie KL, Jebb SA. Prevalence of obesity in Great Britain. Obes Rev. 2005;6:11-2.
35. Cameron AJ, Welborn TA, Zimmet PZ, Dunstan DW, Owen N, Salmon J, et al. Overweight and obesity in Australia: the 1999-2000 Australian Diabetes, Obesity and Lifestyle Study (AusDiab). Med J Aust. 2003;178:427-32.

36. Macdonald SM, Reeder BA, Chen Y, Despres JP. Obesity in Canada: a descriptive analysis. Canadian Heart Health Surveys Research Group. CMAJ. 1997;157:S3-9.

37. Marques-Vidal P, Dias CM. Trends in overweight and obesity in Portugal: the National Health Surveys 1995-6 and 1998-9. Obes Res. 2005;13:1141-5.

38. Gutie'rrez-Fisac JL, Regidor E, Banegas JR, Rodriguez Artalejo F. The size of obesity differences associated with educational level in Spain, 1987 and 1995/97. J Epidemiol Commun Health. 2002;56:457-60.

39. Pedro MV, Murielle B, Vincent M, Fred P, Gerard W, Peter V. Prevalence of obesity and abdominal obesity in the Lausanne population. BMC Public Health. 2008:8:330

\section{Submit your next manuscript to BioMed Central and take full advantage of:}

- Convenient online submission

- Thorough peer review

- No space constraints or color figure charges

- Immediate publication on acceptance

- Inclusion in PubMed, CAS, Scopus and Google Scholar

- Research which is freely available for redistribution 